\title{
Research progress of the transcription factor Brn4 (Review)
}

\author{
YUYING WU $^{1}$, XUNRUI ZHANG $^{2}$, JUE WANG $^{1}$, GUOHUA JIN $^{1}$ and XINHUA ZHANG ${ }^{1}$ \\ ${ }^{1}$ Department of Anatomy, Co-Innovation Center of Neuroregeneration, Medical School, \\ Nantong University, Nantong, Jiangsu 226001; ${ }^{2}$ Department of Clinical Medicine, \\ Faculty of Medicine, Xinglin College, Nantong University, Nantong, Jiangsu 226008, P.R. China
}

Received April 6, 2020; Accepted November 9, 2020

DOI: $10.3892 / \mathrm{mmr} .2020 .11818$

\begin{abstract}
Brain 4 (Brn4) is a transcription factor belonging to the POU3 family, and it is important for the embryonic development of the neural tube, inner ear and pancreas. In addition, it serves a crucial role in neural stem cell differentiation and reprogramming. The present review aimed to summarize the chromosomal location, species homology, protein molecular structure and tissue distribution of Brn4, in addition to its biological processes, with the aim of providing a reference of its structure and function for further studies, and its potential use as a gene therapy target.
\end{abstract}

\section{Contents}

1. Introduction

2. Chromosomal location and species homology

3. Protein molecular structure and tissue distribution

4. Related biological processes of Brn4

5. Conclusion

\section{Introduction}

The transcription factor brain (Brn)4 is a member of the POU protein family. In 1984, Parslow et al (1) first identified a highly conserved sequence $\sim 70$ base pairs upstream of the transcription initiation site of the immunoglobulin heavy and light chain genes, which was considered to be the area involved in the transcriptional regulation of gene expression. Subsequently, DNA elements with similar functions and highly conserved sequences were found at the origin of adenoviral DNA replication and at the promoters of nucleolar small RNA and Histone 2B genes. Given the similarity of the 150-160 amino acids in the sequences in the mammalian proteins, pituitary-specific positive transcription

Correspondence to: Professor Xinhua Zhang, Department of Anatomy, Co-Innovation Center of Neuroregeneration, Medical School, Nantong University, 19 Qixiu Road, Nantong, Jiangsu 226001, P.R. China

E-mail: zhangxinhua@ntu.edu.cn

Key words: brain 4, differentiation, inner ear, neural stem cells, pancreas, reprogramming factor 1, Oct1, 2 and nematode Uncoordinated-86, the homologous sequence was named the POU domain (an acronym of the transcription factors) (2).

The POU domain is a binding site for DNA binding proteins. It comprises two subdomains linked by a 15-56 amino acid sequence junction region: i) The N-terminus, which contains the POU-specific domain $\left(\mathrm{POU}_{\mathrm{S}}\right)$ comprising 76-78 amino acids, and ii) the $\mathrm{C}$-terminus, which comprises the POU homology domain $\left(\mathrm{POU}_{\mathrm{H}}\right)$ composed of 60 amino acids (3). Proteins with a POU domain are named POU proteins, and serve as transcription factors that have important roles in embryonic development and cell fate-directed processes by binding to specific nucleotide sequences and regulating the transcription of downstream target genes (4). According to the degree of homology of the POU domain, the POU gene can be divided into six classes, which encode the POU1-6 protein families, respectively, each of which contains different members (5).

The POU3 family contains four members, Tst-1 [also known as POU domain, class 3 , transcription factor 1 (POU3F1), Oct6, Test1, and SCIP], Brn1 (also known as POU3F3 and Oct8), Brn2 (also known as POU3F2 and Oct7) and Brn4 (also known as POU3F4, Oct9, deafness 3 and deafness X-linked 2). Tst-1 was originally identified in rat testes and glial cells, as well as in the developing brain and skin (5), and it is an important regulator of neurogenesis and epidermal differentiation (6). It has a dual regulatory function, not only does it activate neural lineage genes (such as Sox2), but it also represses neural-inhibitory signals (such as Wnt and bone morphogenetic protein), thus inhibiting cell proliferation $(7,8)$. The degradation of POU3F1, caused by numerous factors such as DNA damage, starvation, and oxidative stress, was reported to induce neural tube defects (9). Brn1 is involved in the development of the central nervous system, and its loss-of-function mutations were identified to cause developmental delays, intellectual disability and impairments in language skills (10). It was also found to be expressed in the developing kidney (11). In previous studies, Brn1 knockout mice were discovered to have neurological defects, including locomotor and auditory impairments, but also a thicker ascending loop of the limb of Henle and decreased numbers of nephrons, thus resulting in renal failure and perinatal death $(12,13)$. Brn2 has been reported to serve an important role in the development of the central nervous system; it has been associated with bipolar disorder (14), and it promotes neurogenesis by regulating the expression levels of neurotrophin 3 (15). Brn2 knockout mice 
were also revealed to suffer from cognitive impairment and decreased numbers of newborn neurons were found in the dentate gyrus of the hippocampus (16). Another previous study suggested that Brn2 may promote human gastric carcinoma cell proliferation, migration and invasion by binding to the promoter of tumor-associated NADH oxidase (17). It was also shown to serve a role in the development of hepatocellular carcinoma through the long non-coding RNA brain cytoplasmic RNA 1/microRNA-490-3p/Brn2 axis (18). Brn4, also known as POU3F4, Oct9, deafness 3 and deafness $\mathrm{X}$-linked 2, was named after it was initially discovered in brain tissue (19). The following sections of the present review aimed to concisely summarize the research progress on Brn4 regarding its chromosomal location and species homology, protein molecular structure and tissue distribution, and related biological processes.

\section{Chromosomal location and species homology}

Brn4 is a single copy gene located on the human chromosome X q21.1, spanning 3,867 nucleotides. Two polydeoxyadenine nucleotides in the POU3 family gene sequence are considered to be formed by the reverse transcription of mRNA and re-entry into chromosomal sequences via genetic recombination (20). In the absence of introns, Brn4 mRNA leaves the nucleus and enters the cytoplasm without undergoing post-transcriptional splicing, thus resulting in rapid gene expression (20). Brn4 was formed before the human and rodent gene duplication that occurred during evolution (5); therefore, it has high homology between humans and mice, and investigations using rodent models can provide valuable references for studies of clinical diseases. In addition, a previous study of a lactose operon reporter gene identified the presence of $\geq 2$ positive cis-regulatory elements of $6 \mathrm{~kb}$ in length upstream of the promoter sequence in Brn4 (21), indicating that Brn 4 may be highly expressed at certain stages of development and may be important in histogenesis.

\section{Protein molecular structure and tissue distribution}

The transcription factor Brn4 is a DNA-binding protein that recognizes a specific octamer motif (ATGCAAAT) (4). Brn4 comprises 361 amino acids and has a molecular weight of $39.43 \mathrm{kDa}$. Both the $\mathrm{POU}_{\mathrm{S}}$ and $\mathrm{POU}_{\mathrm{H}}$ domains of Brn4 contain a helix-turn-helix motif, which can form a hairpin structure that binds DNA sequences and exerts biological effects such as transcriptional activation (Fig. 1) (4). During development in mammals, the POU3 gene family has been reported to be widely expressed in ectoderm-derived tissue, such as the nervous system and auditory vesicles (22). In addition, Brn4 has been detected in the embryonic pancreas and adult glucagon cells $(23,24)$. A previous study investigating the role of the POU3 gene during development in Xenopus laevis found that Brn4 was expressed in the embryonic neural tube, brain, developmental ear vesicles, distal renal tubules and connective tubules (11). RNA sequencing results of the genome-wide analysis of 272 mouse cell and tissue types revealed the widespread expression of Brn4 during nervous system development, including within the neural crest, neuroectoderm, hypothalamus, pituitary, hippocampus and
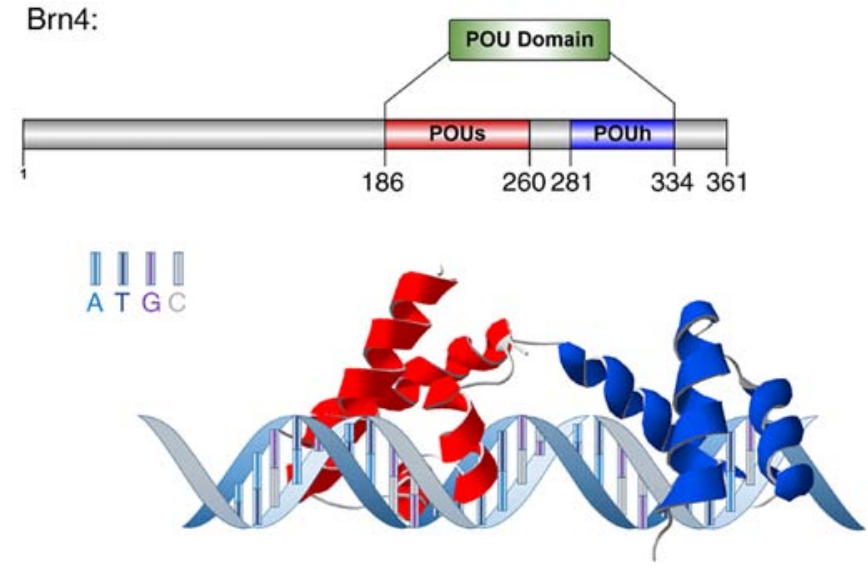

Figure 1. Structure of the Brn4-POU domain bound to DNA. POU $\mathrm{S}_{\mathrm{S}}$ and $\mathrm{POU}_{\mathrm{H}}$ form a helix-turn-helix motif, which can form a hairpin structure combined with the DNA sequence to exert biological effects. The red represents POU $_{\mathrm{S}}$ and the blue represents $\mathrm{POU}_{\mathrm{H}}$. Brn4, brain 4; $\mathrm{POU}_{\mathrm{H}}$, POU homology domain; $\mathrm{POU}_{\mathrm{S}}$, POU-specific domain.

inner ear (5). However, in contrast to the extensive distribution in embryonic development, in adult animals, Brn4 expression was reported to be limited to a small part of the forebrain, including the supraoptic nucleus and paraventricular nucleus of the thalamus.

\section{Related biological processes of Brn4}

Inner ear development. The inner ear is part of the anatomical structure of the ear and is located in the cavity of the sacral rock (25). Through a series of complicated canals, it forms a structure called the labyrinth, which consists of the bony and membranous labyrinths (25). The bony labyrinth contains the vestibular system, which is associated with balance, and the cochlea, which is associated with hearing (26). The cochlea converts sound into nerve impulses that transmit external signals to the central nervous system through the auditory nerve, thus resulting in hearing (26). Inner ear development is a complex process involving a series of morphological changes caused by the interaction between ectodermal epithelial cells and mesenchymal cells (27).

Brn4 is abundantly expressed in the mesenchymal cells of the embryonic ear (Fig. 2), which not only benefits the survival of spiral ganglion neurons (SGNs), but also stimulates SGNs to extend axon bundles and eventually form synapses with surrounding hair cells (28). The gap junctions between cochlear cells facilitate $\mathrm{K}^{+}$transmission, thus resulting in a high resting potential for sensory hair cell excitation (29). Brn4 was reported to promote the assembly and localization of connexins at the cochlear support cell borders, thereby maintaining proper intra-cochlear lymphatic potential for the efficient transmission of sound (22). Mice with targeted mutations in Brn4 demonstrated abnormal development in the inner ear interstitial compartment and showed signs of numerous behavioral changes associated with auditory and vestibular system function defects, including vertical nodding movement, gait abnormality and hearing loss (30). As both the temporal bone and cochlea originate from mesenchymal cells of the embryonic ear, anatomical and histological analyses 


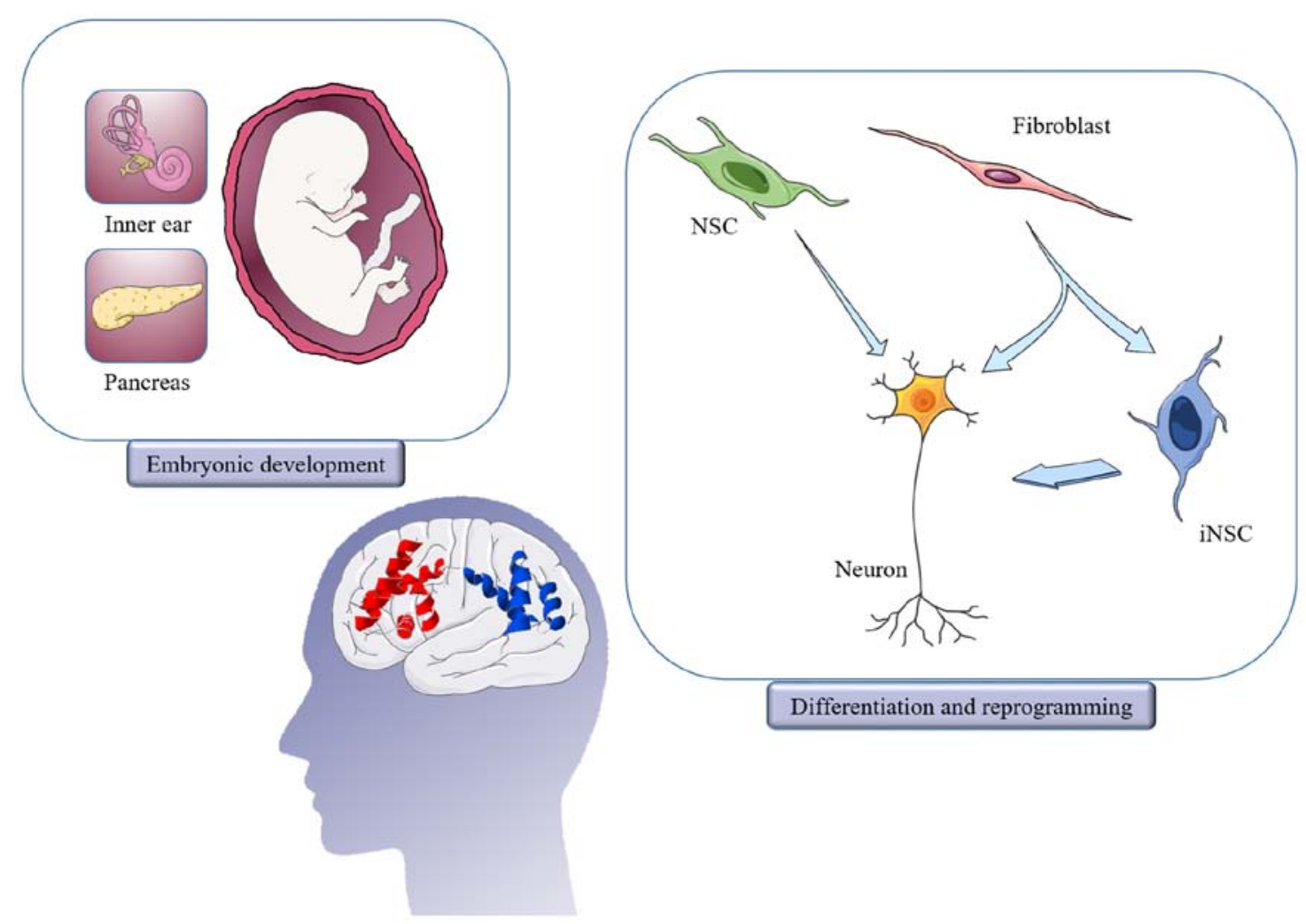

Figure 2. Reported biological functions of Brn4. Brn4 reportedly promotes the development of the embryonic inner ear and pancreas. It can also induce NSCs to differentiate into neurons and help reprogram fibroblasts into iNSCs. Brn4, brain 4; iNSC, inducible NSC; NSC, neural stem cell.

have indicated that Brn4 mutant mice have temporal bone dysplasia, enlargement of the inner ear canal, constriction in the bony labyrinth, thinning of the chamber wall, cochlear dysplasia, reduction in cochlear coiling and changes in the size and shape of the stapes footplate (30).

DFN3 is the most common type of X-chromosome-linked hereditary hearing loss (31). More than two decades ago, Brn4 was found to be a specific pathogenic factor in this disease (32-34). The pathogenic molecular mechanism of DFN3 simultaneously involves the sound conduction and sensory system and is based on structural changes in the Brn4 protein. Imaging examinations in patients have also revealed that Brn4 mutations can result in cochlear morphological abnormalities, internal auditory canal expansion and thickening of the stapes footplate (35). Cerebrospinal fluid was observed to flow into the vestibule through the dilated inner auditory canal, and consequently promoted perilymphatic gusher following the removal of the stapedial footplate during inner ear surgery (36). The disease is characterized by severe mixed hearing loss in males, whereas female carriers usually do not experience deafness. However, female carriers may have varying degrees of hearing threshold changes, mild semicircular canal dilatation and postural abnormalities (37). In previous years, genetic sequencing of families with DFN3 has revealed that almost all affected individuals have Brn4 gene segments with nonsense, missense or frameshift mutations, and even de novo genome deletion, thus resulting in abnormal protein structure and function (37-44). Chromosome translocations and deletions have also been detected upstream of Brn4 (up to $900 \mathrm{~kb}$ upstream), suggesting that some cis-regulatory elements may be present in these regions to regulate the gene expression (45). Imaging analyses of patients with DFN3 with Brn4 mutations revealed that the patients also had a high incidence of hypothalamic malformation, in addition to inner ear structural abnormalities such as stapes fixation and multiple vestibular diverticulum $(46,47)$.

Although Brn4 gene mutations have been widely confirmed to cause severe inner ear dysplasia, its specific molecular mechanism remains unclear. Moreover, how to effectively prevent the occurrence and development of this genetic disease and how to correct the abnormal cochlear structure caused by the mutation of Brn4 require further research.

Pancreas development. The pancreas originates from the dorsal and ventral buds of the endoderm, which are later referred to as the dorsal and ventral lobes; these develop into the 'tail' and 'head' of the adult pancreas, respectively (48). The pancreas functions as both an exocrine and endocrine gland. The endocrine function involves the pancreatic islets, which lack a fixed form and are found scattered throughout the pancreas (49). The most representative cells in the islets are glucagon-secreting $\alpha$ cells (15-20\% of islet cells) and insulin-secreting $\beta$ cells (65-80\% of islet cells) (50). The balance of insulin and glucagon is crucial for the maintenance of blood glucose homeostasis (50).

Islet $\alpha$ cells are the first endocrine cells formed in the developing pancreas on embryonic day 9.5 in mice, and Brn4 was revealed to promote their differentiation (Fig. 2) (51-53). Islet $\alpha$ cells first express the proglucagon gene, and the produced proglucagon is further processed into glucagon, which increases blood glucose levels (53). Previous studies identified that the proximal G1 promoter element of the 
proglucagon gene, an AT-rich DNA sequence, was the binding site for Brn4 (24). Upregulated expression levels of Brn4 have been detected in islet cell lines producing glucagon and rat pancreatic islet cells, thus indicating its importance in pancreatic development. Heller et al (23) reported that Brn4, expressed in the E10 pancreas (Fig. 2), was the only confirmed islet $\alpha$ cell-specific transcription factor. However, Brn4 deletion did not generate abnormalities in pancreatic bud formation, pancreatic islet $\alpha$ cell numbers or physiological function in mice. Therefore, the synthesis and secretion of glucagon appears to depend on the participation of numerous factors, which may overlap in function.

Clinically, diabetes is typically treated with oral medication or insulin injection (54). The complications of diabetes have long been a prominent cause of human disabilities such as musculoskeletal abnormalities and microangiopathy $(54,55)$. One previous study discovered that the differentiated islet cells from human marrow mesenchymal cells highly expressed pancreatic transcription factors, such as Brn4, in induced islet-like cell aggregates, suggesting that Brn4 may be targeted to induce the regeneration of islet cells to treat clinical diseases including diabetes, pancreatic cancer and abnormal glucose metabolism (56).

Differentiation of neural stem cells. Self-proliferating neural stem cells (NSCs) are present throughout life in mammalian brains. These cells are mainly distributed in the subventricular zone and the hippocampal subgranular zone, and they can differentiate into neurons and glial cells (57). Since Brn4 was found to mediate striatal neuron precursor differentiation in 1999 (58), its role in neural regeneration has attracted significant attention (Fig. 2). Nuclear receptor-related 1 (Nurr1), a midbrain dopaminergic (DA) neuron-specific transcription factor, was reported to promote the differentiation of NSCs into DA neurons, increase the levels of dopamine in the striatum and ameliorate behavior defects in rats with Parkinson's disease. The expression of Brn4 also promoted the Nurr1-induced significant increase in the viability and maturity of DA neurons (59). Brn4 was also discovered to induce the expression of glial cell line-derived neurotrophic factor, which contributed to the survival and maturation of DA neurons, together with its receptors, GDNF family receptor $\alpha-1$ and Ret (60). In addition, following denervation surgery, the expression levels of Brn4 in the hippocampus of rats were found to be upregulated, and reached a peak at 14 days post-injury (61). Functional experiments have indicated that Brn4 not only promotes the differentiation of NSCs into neurons but also enhances the maturation of neurons $(61,62)$. This change in Brn4 may be due in part to the activation of the PI3K/AKT signaling pathway caused by upregulated expression levels of insulin-like growth factor (63). In addition, the paired box protein Pax 6/barrier-to-autointegration factor complex was demonstrated to drive neurogenesis by directly activating the expression of transcription factors, such as Brn4, during neurodevelopment (64). Investigations to determine target genes of Brn4 using RNA sequencing have revealed that, alongside the expression of Brn4, the expression levels of genes involved in neuronal development and maturation were upregulated, whereas those of genes associated with maintaining the pluripotency of NSCs were downregulated.
Furthermore, C-terminal-binding protein 2 and Notch2 were suggested to be direct targets of Brn4 $(65,66)$.

Fetal brain tissue can be used for cell replacement therapy in neurodegenerative diseases, such as Parkinson's disease, but it is limited by donor deficiency and cannot be standardized (67). Fortunately, the induced differentiation into specific cell groups after the expansion of NSCs in vitro can solve this problem. For example, in both the midbrain and the hippocampus, Brn 4 promoted the differentiation of NSCs into neurons (Fig. 2) and the maturation of new neurons $(58-62,68)$. Therefore, Brn 4 may provide a target for novel drugs in the treatment of neurodegenerative diseases.

Reprogramming. In 1998, Thomson et al (69) proposed that blastocyst-derived embryonic stem cells may be used as a clinical treatment for diseases such as type 1 diabetes and Parkinson's disease. Since this discovery, the cell transplantation theory has gradually become a research focus. However, there are ethical problems in obtaining stem cells from embryos, and transplant rejection is common during allogeneic transplantation (69). Therefore, how to obtain cell sources conveniently and quickly and eliminate rejection reactions has become an urgent problem that must be solved. In 2006, Takahashi and Yamanaka (70) identified four factors, Oct3/4 (also known as POU5F1), Krüppel-like factor 4 (KLF4), Sox 2 and c-Myc together referred to as OKSM, that induced embryonic or adult mouse fibroblasts to differentiate into induced pluripotent stem cells (iPSCs) in vitro; the results were subsequently confirmed in human cells (71). However, the activation of c-Myc, a proto-oncogene, was revealed to result in the formation of tumors in mice transplanted with iPSCs (70). Subsequently, some researchers found that induced NSC (iNSC) colonies were produced after culturing mouse iPSCs induced by OKSM in NSC-specific medium for $\geq 8$ days (72). As with Oct 4 , Brn 2 and 4 are also members of POU protein family and have important effects on nervous system development (5). Therefore, some researchers are focusing on the roles of Brn 2 and 4 in cell reprogramming.

The co-overexpression of Brn2, Sox 2 and forkhead box G2 was identified to be able to reprogram human or mouse fibroblasts and astrocytes into neural precursor cells, which are also called induced DA precursors, owing to their DA differentiation ability (73-75). Under spontaneous neuronal differentiation condition, these induced neural precursor cells were observed to differentiate into glutamatergic and GABAergic neuronal subtypes (73). In previous studies, Brn2 combined with guanine nucleotide-binding protein subunit $\beta$-like protein and myelin transcription factor 1-like protein was used to reprogram somatic cells into functional neurons (76-79). A previous study suggested that Brn2 itself may be sufficient to achieve the aforementioned somatic cell reprogramming effect, and that changes in cell culture conditions determine the direction of induction (80).

Brn4, in combination with Sox 2, KLF4 and c-Myc is called BSKM; BSKM was found to successfully induce fibroblast reprogramming into iNSCs (Fig. 2). These cells, after being transplanted into the stem cell pool in the adult mouse brain, exhibited true pluripotency in terms of proliferation and differentiation into neurons and glial cells $(81,82)$. The reprogramming efficiency was further improved by 
the addition of E47 or transcription factor 3 (83). Oct4 and Brn4 were discovered to bind to Sox 2 and form a dimer in a similar manner by cooperativity by sequencing, a method to determine the cooperativity parameters of transcription factors (84). Although both OKSM and BSKM can reprogram somatic cells into iNSCs (85), they exhibit several differences; for example, owing to the subtle differences between Oct4 and Brn4 in the $\mathrm{POU}_{\mathrm{S}}$ domain (86), BSKM was observed to directly transform somatic cells into iNSCs without requiring the state of transient iPSCs induced by OKSM (Fig. 2) $(81,86)$. Thus, BSKM may have lower tumorgenicity and an enhanced clinical practical value.

Moreover, reprogramming human or mouse fibroblasts or astrocytes into functional neurons or neuronal precursor cells by Brn4 is not uncommon (87-89), and these studies suggested that neurons induced by Brn4 in vitro could be used as cell resources for substitutive therapy to treat nerve injury or neurodegenerative diseases. However, numerous issues require further investigations and research, such as whether induced neurons can completely replace the damaged cells; whether these cells have the long-term characteristics of nerve cells in producing and conducting excitation; and how to accurately intervene to modulate the direction, cycle and speed of cell differentiation.

\section{Conclusion}

With further medical advancements, the survival rate of patients with various genetic, chronic and nervous system diseases has increased significantly (90). However, improving patient comfort and wellbeing is currently the ultimate goal of medical care $(90,91)$. As aforementioned, Brn4 was discovered to promote the survival and synaptic growth of SGNs in the inner ear (28) and maintain proper intra-cochlear lymphatic potential by regulating connexins (22). However, to the best of our knowledge, its downstream target genes and the specific molecular mechanisms leading to structural abnormalities of the inner ear remain unclear. It was hypothesized that Brn4 may not only promote the growth of neurons, but it may also directly affect the signal transduction between cells and serve an important role in the osteogenic differentiation of the inner ear. Brn $4^{-/}$mice were reported to exhibit vertical nodding and an abnormal gait (30), thereby suggesting that Brn4 might affect the sense of balance and voluntary movement function.

Although Brn4 was once considered a specific transcription factor of islet $\alpha$ cells that upregulates the expression of the proglucagon gene, the pancreatic development of $\mathrm{Brn} 4^{-/}$mice is not significantly altered, and Brn4 expression levels were also upregulated in insulin-like cells with the function of decreasing blood glucose in diabetic model mice $(23,24,51,52,56)$. However, to the best of our knowledge, the mechanism via which Brn4 maintains blood glucose stability and the quantitative balance among different islet cell types has not been reported. It can be suggested that Brn4 may provide an adequate energy supply for insulin synthesis in islet $\beta$ cells by promoting glucagon secretion in islet $\alpha$ cells. Accordingly, the feedback regulation of both hormones and blood glucose levels would ultimately maintain Brn4 homeostasis.

Brn4 was identified to not only promote the differentiation of NSCs and the maturation of newborn neurons (59-61,63-66), but also induced somatic cells to transform into neural lineage cells (87-89). However, the majority of the previous studies have focused on the number rather than the function of neurons following Brn4-induced differentiation. Further in-depth studies are required to determine whether the neurons induced by Brn4 have the long-term function of generating and conducting excitation; whether they produce effective synaptic connections with surrounding cells after being transplanted into the injured site; and how to improve the conversion ratio of neurons.

The microenvironment affects cell fate transitions; therefore, Brn4-mediated downstream gene transcription may provide a suitable microenvironment for neurogenesis, and the expression changes observed in numerous neural lineage-related genes following Brn4 treatment support this hypothesis (65). Previously, Brn4 was revealed to be a driving factor in neuroendocrine differentiation, thus promoting the occurrence and development of castration-resistant prostate cancer, together with Brn2. It was reported to be used as both a predictive marker of advanced castration-resistant prostate cancer and as a novel target to address the issue of resistance to enzalutamide treatment (92).

Due to its specificity of distribution and its high degree of homology across species, Brn4 is clearly important in development and biological functions including promoting the differentiation of NSCs into neurons and inducing reprogramming of somatic cells (Fig. 2). However, to the best of our knowledge, multiple aspects of the regulatory mechanism of its downstream biological processes remain unknown. Elucidation of the links between Brn4 and clinical diseases will require further investigations and experimental data. The present review aimed to concisely summarize the reported structure and biological properties of Brn4, with the aim of providing novel ideas for research in related fields.

\section{Acknowledgements}

Not applicable.

\section{Funding}

The present review was funded by grants from The National Natural Science Foundation of China (grant no. 31171038), Jiangsu Natural Science Foundation (grant no. BK2011385), Jiangsu '333' program funding (grant no. BRA2016450) and The Application Research Project of Nantong City (grant no. MS12017015-3).

\section{Availability of data and materials}

Not applicable.

\section{Authors' contributions}

YW collected the data and drafted the manuscript. XuZ and JW assisted with manuscript preparation. GJ and $\mathrm{XiZ}$ revised the final manuscript. XiZ conceived and designed the idea for this paper. All authors read and approved the final manuscript. 


\section{Ethics approval and consent to participate}

Not applicable.

\section{Patient consent for publication}

Not applicable.

\section{Competing interests}

The authors declare that they have no competing interests.

\section{References}

1. Parslow TG, Blair DL, Murphy WJ and Granner DK: Structure of the 5' ends of immunoglobulin genes: A novel conserved sequence. Proc Natl Acad Sci USA 81: 2650-2654, 1984.

2. Herr W, Sturm RA, Clerc RG, Corcoran LM, Baltimore D, Sharp PA, Ingraham HA, Rosenfeld MG, Finney M, Ruvkun G, et al: The POU domain: A large conserved region in the mammalian pit-1, oct-1, 2, and Caenorhabditis elegans unc-86 gene products. Genes Dev 2: 1513-1516, 1988

3. Liu L, Li Y, Wang Y, Zhao P, Wei S, Li Z, Chang H and He H Biochemical characterization and functional analysis of the POU transcription factor POU-M2 of Bombyx mori. Int J Biol Macromol 86: 701-708, 2016.

4. Tang X and Engstrom Y: Regulation of immune and tissue homeostasis by Drosophila POU factors. Insect Biochem Mol Biol 109: 24-30, 2019.

5. Malik V, Zimmer D and Jauch R: Diversity among POU transcription factors in chromatin recognition and cell fate reprogramming. Cell Mol Life Sci 75: 1587-1612, 2018.

6. Fionda C, Di Bona D, Kosta A, Stabile H, Santoni A and Cippitelli M: The POU-domain transcription factor Oct-6/POU3F1 as a regulator of cellular response to genotoxic stress. Cancers (Basel) 11: 810, 2019.

7. Barral A, Rollan I, Sanchez-Iranzo H, Jawaid W, Badia-Careaga C, Menchero S, Gomez MJ, Torroja C, Sanchez-Cabo F, Göttgens B, et al: Nanog regulates Pou3f1 expression at the exit from pluripotency during gastrulation. Biol Open 8: bio046367, 2019.

8. Song L, Sun N, Peng G, Chen J, Han JD and Jing N: Genome-wide ChIP-seq and RNA-seq analyses of Pou3f1 during mouse pluripotent stem cell neural fate commitment. Genom Data 5: 375-377, 2015

9. Li G, Jiapaer Z, Weng R, Hui Y, Jia W, Xi J, Wang G, Zhu S, Zhang X, Feng D, et al: Dysregulation of the SIRT1/OCT6 axis contributes to environmental stress-induced neural induction defects. Stem Cell Reports 8: 1270-1286, 2017.

10. Snijders Blok L, Kleefstra T, Venselaar H, Maas S, Kroes HY, Lachmeijer AM, van Gassen KL, Firth HV, Tomkins S, Bodek S, et al: De novo variants disturbing the transactivation capacity of POU3F3 cause a characteristic neurodevelopmental disorder. Am J Hum Genet 105: 403-412, 2019.

11. Cosse-Etchepare C, Gervi I, Buisson I, Formery L, Schubert M, Riou JF, Umbhauer M and Le Bouffant R: Pou3f transcription factor expression during embryonic development highlights distinct pou3f 3 and pou3f4 localization in the Xenopus laevis kidney. Int J Dev Biol 62: 325-333, 2018.

12. Kumar S, Rathkolb B, Kemter E, Sabrautzki S, Michel D, Adler T, Becker L, Beckers J, Busch DH, Garrett L, et al: Generation and standardized, systemic phenotypic analysis of Pou3f3L423P mutant mice. PLoS One 11: e0150472, 2016.

13. Rieger A, Kemter E, Kumar S, Popper B, Aigner B, Wolf E, Wanke R and Blutke A: Missense mutation of POU domain class 3 transcription factor 3 in Pou3f3L423P mice causes reduced nephron number and impaired development of the thick ascending limb of the loop of henle. PLoS One 11: e0158977, 2016.

14. Chen C, Meng Q, Xia Y, Ding C, Wang L, Dai R, Cheng L, Gunaratne P, Gibbs RA, Min S, et al: The transcription factor POU3F2 regulates a gene coexpression network in brain tissue from patients with psychiatric disorders. Sci Transl Med 10: eaat8178, 2018

15. Lin YJ, Hsin IL, Sun HS, Lin S, Lai YL, Chen HY, Chen TY, Chen YP, Shen YT and Wu HM: NTF3 is a novel target gene of the transcription factor POU3F2 and is required for neuronal differentiation. Mol Neurobiol 55: 8403-8413, 2018.
16. Hashizume K, Yamanaka M and Ueda S: POU3F2 participates in cognitive function and adult hippocampal neurogenesis via mammalian-characteristic amino acid repeats. Genes Brain Behav 17: 118-125, 2018

17. Chen HY, Lee YH, Chen HY, Yeh CA, Chueh PJ and Lin YM Capsaicin inhibited aggressive phenotypes through downregulation of tumor-associated NADH Oxidase (tNOX) by POU domain transcription factor POU3F2. Molecules 21: 733, 2016.

18. Ding S, Jin Y, Hao Q, Kang $Y$ and Ma R: LncRNA BCYRN1/miR-490-3p/POU3F2, served as a ceRNA network, is connected with worse survival rate of hepatocellular carcinoma patients and promotes tumor cell growth and metastasis. Cancer Cell Int 20: 6, 2020.

19. Serrano-Saiz E, Leyva-Diaz E, De La Cruz E and Hobert O: BRN3-type POU homeobox genes maintain the identity of mature postmitotic neurons in nematodes and mice. Curr Biol 28 2813-2823.e2, 2018.

20. Hara Y, Rovescalli AC, Kim Y and Nirenberg M: Structure and evolution of four POU domain genes expressed in mouse brain. Proc Natl Acad Sci USA 89: 3280-3284, 1992.

21. Heydemann A, Nguyen LC and Crenshaw EB III: Regulatory regions from the Brn4 promoter direct LACZ expression to the developing forebrain and neural tube. Brain Res Dev Brain Res 128: 83-90, 2001.

22. Phippard D, Heydemann A, Lechner M, Lu L, Lee D, Kyin T and Crenshaw EB III: Changes in the subcellular localization of the Brn4 gene product precede mesenchymal remodeling of the otic capsule. Hear Res 120: 77-85, 1998.

23. Heller RS, Stoffers DA, Liu A, Schedl A, Crenshaw EB III, Madsen OD and Serup P: The role of Brn4/Pou3f4 and Pax6 in forming the pancreatic glucagon cell identity. Dev Biol 268: $123-134,2004$.

24. Hussain MA, Lee J, Miller CP and Habener JF: POU domain transcription factor brain 4 confers pancreatic alpha-cell-specific expression of the proglucagon gene through interaction with a novel proximal promoter G1 element. Mol Cell Biol 17: 7186-7194, 1997.

25. Lim R and Brichta AM: Anatomical and physiological development of the human inner ear. Hear Res 338: 9-21, 2016.

26. Kanzaki S: Gene delivery into the inner ear and its clinical implications for hearing and balance. Molecules 23: 2507, 2018.

27. Roccio M and Edge AS: Inner ear organoids: New tools to understand neurosensory cell development, degeneration and regeneration. Development 146: dev177188, 2019.

28. Brooks PM, Rose KP, MacRae ML, Rangoussis KM, Gurjar M, Hertzano R and Coate TM: Pou3f4-expressing otic mesenchyme cells promote spiral ganglion neuron survival in the postnatal mouse cochlea. J Comp Neurol 528: 1967-1985, 2020

29. Kidokoro Y, Karasawa K, Minowa O, Sugitani Y, Noda T, Ikeda K and Kamiya K: Deficiency of transcription factor Brn4 disrupts cochlear gap junction plaques in a model of DFN3 non-syndromic deafness. PLoS One 9: e108216, 2014

30. Phippard D, Lu L, Lee D, Saunders JC and Crenshaw EB III Targeted mutagenesis of the POU-domain gene Brn4/Pou3f4 causes developmental defects in the inner ear. J Neurosci 19: 5980-5989, 1999.

31. de Kok YJ, van der Maarel SM, Bitner-Glindzicz M, Huber I, Monaco AP, Malcolm S, Pembrey ME, Ropers HH and Cremers FP: Association between X-linked mixed deafness and mutations in the POU domain gene POU3F4. Science 267: 685-688, 1995 .

32. Ocak E, Duman D and Tekin M: Genetic causes of inner ear anomalies: A review from the Turkish study group for inner ear anomalies. Balkan Med J 36: 206-211, 2019.

33. DeSmidt AA, Zou B, Grati M, Yan D, Mittal R, Yao Q, Richmond MT, Denyer S, Liu XZ and Lu Z: Zebrafish model for nonsyndromic X-linked sensorineural deafness, DFNX1. Anat Rec (Hoboken) 303: 544-555, 2019.

34. Yizhar-Barnea O, Valensisi C, Jayavelu ND, Kishore K, Andrus C, Koffler-Brill T, Ushakov K, Perl K, Noy Y, Bhonker Y, et al: DNA methylation dynamics during embryonic development and postnatal maturation of the mouse auditory sensory epithelium. Sci Rep 8: 17348, 2018.

35. Gong WX, Gong RZ and Zhao B: HRCT and MRI findings in X-linked non-syndromic deafness patients with a POU3F4 mutation. Int J Pediatr Otorhinolaryngol 78: 1756-1762, 2014

36. Corvino V, Apisa P, Malesci R, Laria C, Auletta G and Franzé A: $\mathrm{X}$-linked sensorineural hearing loss: A literature review. Curr Genomics 19: 327-338, 2018. 
37. Barashkov NA, Klarov LA, Teryutin FM, Solovyev AV, Pshennikova VG, Konnikova EE, Romanov GP, Tobokhov AV, Morozov IV, Bondar AA, et al: A novel pathogenic variant c.975G $>$ A (p.Trp325*) in the POU3F4 gene in Yakut family (Eastern Siberia, Russia) with the X-linked deafness-2 (DFNX2) Int J Pediatr Otorhinolaryngol 104: 94-97, 2018.

38. Giannantonio S, Agolini E, Scorpecci A, Anzivino R, Bellacchio E, Cocciadiferro D, Novelli A, Digilio MC and Marsella P: Genetic identification and molecular modeling characterization of a novel POU3F4 variant in two Italian deaf brothers. Int J Pediatr Otorhinolaryngol 129: 109790, 2020.

39. Ozyilmaz B, Mercan GC, Kirbiyik O, Özdemir TR, Özkara S, Kaya ÖÖ, Kutbay YB, Erdoğan KM, Güvenç MS and Koç A: First-line molecular genetic evaluation of autosomal recessive non-syndromic hearing loss. Turk Arch Otorhinolaryngol 57: 140-148, 2019.

40. Jang JH, Oh J, Han JH, Park HR, Kim BJ, Lee S, Kim MY, Lee S, Oh DY, Choung YH and Choi BY: Identification of a novel frameshift variant of POU3F4 and genetic counseling of Korean incomplete partition type III subjects based on detailed genotypes. Genet Test Mol Biomarkers 23: 423-427, 2019.

41. Han JJ, Nguyen PD, Oh DY, Han JH, Kim AR, Kim MY, Park HR, Tran LH, Dung NH, Koo JW, et al: Elucidation of the unique mutation spectrum of severe hearing loss in a Vietnamese pediatric population. Sci Rep 9: 1604, 2019.

42. Su Y, Gao X, Huang SS, Mao JN, Huang BQ, Zhao JD, Kang DY, Zhang $X$ and Dai P: Clinical and molecular characterization of POU3F4 mutations in multiple DFNX2 Chinese families. BMC Med Genet 19: 157, 2018.

43. Du W, Han MK, Wang DY, Han B, Zong L, Lan L, Yang J, Shen Q, Xie LY, Yu L, et al: A POU3F4 mutation causes nonsyndromic hearing loss in a Chinese X-linked recessive family. Chin Med J (Engl) 130: 88-92, 2017

44. Wu D, Huang W, Xu Z, Li S, Zhang J, Chen X, Tang Y, Qiu J, Wang Z, Duan X and Zhang L: Clinical and genetic study of 12 Chinese Han families with nonsyndromic deafness. Mol Genet Genomic Med 8: e1177, 2020.

45. Aristidou C, Theodosiou A, Bak M, Mehrjouy MM, Constantinou E, Alexandrou A, Papaevripidou I, ChristophidouAnastasiadou V, Skordis N, Kitsiou-Tzeli S, et al: Position effect, cryptic complexity, and direct gene disruption as disease mechanisms in de novo apparently balanced translocation cases. PLoS One 13: e0205298, 2018.

46. Anderson EA, Ozutemiz C, Miller BS, Moss TJ and Nascene DR: Hypothalamic hamartomas and inner ear diverticula with $\mathrm{X}$-linked stapes gusher syndrome-new associations?. Pediatr Radiol 50: 142-145, 2020

47. Siddiqui A, D'Amico A, Colafati GS, Cicala D, Talenti G, Rajput K, Pinelli L and D'Arco F: Hypothalamic malformations in patients with X-linked deafness and incomplete partition type 3. Neuroradiology 61: 949-952, 2019.

48. Henry BM, Skinningsrud B, Saganiak K, Pękala PA, Walocha JA and Tomaszewski KA: Development of the human pancreas and its vasculature-An integrated review covering anatomical, embryological, histological, and molecular aspects. Ann Anat 221: 115-124, 2019.

49. Zhou Q and Melton DA: Pancreas regeneration. Nature 557: 351-358, 2018.

50. Gromada J, Franklin I and Wollheim CB: Alpha-cells of the endocrine pancreas: 35 years of research but the enigma remains. Endocr Rev 28: 84-116, 2007.

51. Takeda Y, Fujita Y, Sakai K, Abe T, Nakamura T, Yanagimachi T, Sakagami H, Honjo J, Abiko A, Makino Y and Haneda M Expression of transcription factors in MEN1-associated pancreatic neuroendocrine tumors. Endocrinol Diabetes Metab Case Rep 2017: 17-0088, 2017.

52. Li F, Su Y, Cheng Y, Jiang X, Peng Y, Li Y, Lu J, Gu Y, Zhang C, Cao Y, et al: Conditional deletion of Men1 in the pancreatic $\beta$-cell leads to glucagon-expressing tumor development Endocrinology 156: 48-57, 2015

53. Bramswig NC and Kaestner KH: Transcriptional regulation of $\alpha$-cell differentiation. Diabetes Obes Metab 13 (Suppl 1): S13-S20, 2011

54. Tan SY, Mei Wong JL, Sim YJ, Wong SS, Mohamed Elhassan SA, Tan SH, Ling Lim GP, Rong Tay NW, Annan NC, Bhattamisra SK and Candasamy M: Type 1 and 2 diabetes mellitus: A review on current treatment approach and gene therapy as potential intervention. Diabetes Metab Syndr 13: 364-372, 2019.

55. Zamfirov $\mathrm{K}$ and Philippe J: Musculoskeletal complications in diabetes mellitus. Rev Med Suisse 13: 917-921, 2017 (in French).
56. Phadnis SM, Joglekar MV, Dalvi MP, Muthyala S, Nair PD, Ghaskadbi SM, Bhonde RR and Hardikar AA: Human bone marrow-derived mesenchymal cells differentiate and mature into endocrine pancreatic lineage in vivo. Cytotherapy 13: 279-293, 2011.

57. Sueda R, Imayoshi I, Harima Y and Kageyama R: High Hes1 expression and resultant Ascl1 suppression regulate quiescent vs. active neural stem cells in the adult mouse brain. Genes Dev 33 511-523, 2019.

58. Shimazaki T, Arsenijevic Y, Ryan AK, Rosenfeld MG and Weiss S: A role for the POU-III transcription factor Brn-4 in the regulation of striatal neuron precursor differentiation. EMBO J 18: 444-456, 1999

59. Tan X, Zhang L, Qin J, Tian M, Zhu H, Dong C, Zhao H and Jin G: Transplantation of neural stem cells co-transfected with Nurr1 and Brn4 for treatment of Parkinsonian rats. Int J Dev Neurosci 31: 82-87, 2013

60. Tan X, Zhang L, Zhu H, Qin J, Tian M, Dong C, Li H and Jin G: Brn4 and $\mathrm{TH}$ synergistically promote the differentiation of neural stem cells into dopaminergic neurons. Neurosci Lett 571: 23-28, 2014.

61. Zhang X, Jin G, Wang L, Hu W, Tian M, Qin J and Huang H: Brn-4 is upregulated in the deafferented hippocampus and promotes neuronal differentiation of neural progenitors in vitro. Hippocampus 19: 176-186, 2009.

62. Shi J, Jin G, Zhu H, Tian M, Zhang X, Qin J and Tan X: The role of Brn-4 in the regulation of neural stem cell differentiation into neurons. Neurosci Res 67: 8-17, 2010.

63. Zhang X, Zhang L, Cheng X, Guo Y, Sun X, Chen G, Li H, Li P, Lu X, Tian M, et al: IGF-1 promotes Brn-4 expression and neuronal differentiation of neural stem cells via the PI3K/Akt pathway. PLoS One 9: e113801, 2014.

64. Ninkovic J, Steiner-Mezzadri A, Jawerka M, Akinci U, Masserdotti G, Petricca S, Fischer J, von Holst A, Beckers J, Lie CD, et al: The BAF complex interacts with Pax6 in adult neural progenitors to establish a neurogenic cross-regulatory transcriptional network. Cell Stem Cell 13: 403-418, 2013.

65. Guo J, Cheng X, Zhang L, Wang L, Mao Y, Tian G, Xu W, Wu Y, Ma Z, Qin J, et al: Exploration of the Brn4-regulated genes enhancing adult hippocampal neurogenesis by RNA sequencing. J Neurosci Res 95: 2071-2079, 2017.

66. Zhang L, Zhang X, Zhang Y, Xu N, Wang J, Zhu Y and Xia C: Brn4 promotes the differentiation of radial glial cells into neurons by inhibiting CtBP2. Life Sci 254: 116866, 2020.

67. Dhivya V and Balachandar V: Cell replacement therapy is the remedial solution for treating Parkinson's disease. Stem Cell Investig 4: 59, 2017.

68. Tan XF, Qin JB, Jin GH, Tian ML, Li HM, Zhu HX, Zhang XH, Shi JH and Huang Z: Effects of Brn-4 on the neuronal differentiation of neural stem cells derived from rat midbrain. Cell Biol Int 34: 877-882, 2010

69. Thomson JA, Itskovitz-Eldor J, Shapiro SS, Waknitz MA, Swiergiel JJ, Marshall VS and Jones JM: Embryonic stem cell lines derived from human blastocysts. Science 282: 1145-1147, 1998.

70. Takahashi K and Yamanaka S: Induction of pluripotent stem cells from mouse embryonic and adult fibroblast cultures by defined factors. Cell 126: 663-676, 2006.

71. Takahashi K, Tanabe K, Ohnuki M, Narita M, Ichisaka T, Tomoda $\mathrm{K}$ and Yamanaka S: Induction of pluripotent stem cells from adult human fibroblasts by defined factors. Cell 131: 861-872, 2007.

72. Jerabek S, Ng CK, Wu G, Arauzo-Bravo MJ, Kim KP, Esch D, Malik V, Chen Y, Velychko S, MacCarthy CM, et al: Changing POU dimerization preferences converts Oct6 into a pluripotency inducer. EMBO Rep 18: 319-333, 2017.

73. Ma K, Deng X, Xia X, Fan Z, Qi X, Wang Y, Li Y, Ma Y, Chen Q, Peng H, et al: Direct conversion of mouse astrocytes into neural progenitor cells and specific lineages of neurons. Transl Neurodegener 7: 29, 2018

74. Ma Y, Wang K, Pan J, Fan Z, Tian C, Deng X, Ma K, Xia X, Huang $\mathrm{Y}$ and Zheng JC: Induced neural progenitor cells abundantly secrete extracellular vesicles and promote the proliferation of neural progenitors via extracellular signal-regulated kinase pathways. Neurobiol Dis 124: 322-334, 2019.

75. He M, Zhang H, Li Y, Tian C, Tang B, Huang Y and Zheng J: Direct and selective lineage conversion of human fibroblasts to dopaminergic precursors. Neurosci Lett 699: 16-23, 2019.

76. Black JB, Adler AF, Wang HG, D'Ippolito AM, Hutchinson HA, Reddy TE, Pitt GS, Leong KW and Gersbach CA: Targeted epigenetic remodeling of endogenous Loci by CRISPR/Cas9-based transcriptional activators directly converts fibroblasts to neuronal cells. Cell Stem Cell 19: 406-414, 2016. 
77. Chuang W, Sharma A, Shukla P, Li G, Mall M, Rajarajan K Abilez OJ, Hamaguchi R, Wu JC, Wernig M and Wu SM: Partial reprogramming of pluripotent stem cell-derived cardiomyocytes into neurons. Sci Rep 7: 44840, 2017.

78. Luo C, Lee QY, Wapinski O, Castanon R, Nery JR, Mall M, Kareta MS, Cullen SM, Goodell MA, Chang HY, et al: Global DNA methylation remodeling during direct reprogramming of fibroblasts to neurons. Elife 8: e40197, 2019.

79. Treutlein B, Lee QY, Camp JG, Mall M, Koh W, Shariati SA, Sim S, Neff NF, Skotheim JM, Wernig M and Quake SR: Dissecting direct reprogramming from fibroblast to neuron using single-cell RNA-seq. Nature 534: 391-395, 2016.

80. Zhu X, Zhou W, Jin H and Li T: Brn2 alone is sufficient to convert astrocytes into neural progenitors and neurons. Stem Cells Dev 27: 736-744, 2018.

81. Kim SM, Kim JW, Kwak TH, Park SW, Kim KP, Park H, Lim KT, Kang K, Kim J, Yang JH, et al: Generation of integration-free induced neural stem cells from mouse fibroblasts. J Biol Chem 291: 14199-14212, 2016

82. Kwak TH, Hali S, Kim S, Kim J, La H, Kim KP, Hong KH, Shin CY, Kim NH and Han DW: Robust and reproducible generation of induced neural stem cells from human somatic cells by defined factors. Int J Stem Cells 13: 80-92, 2020.

83. Han DW, Tapia N, Hermann A, Hemmer K, Höing S, Araúzo-Bravo MJ, Zaehres H, Wu G, Frank S, Moritz S, et al: Direct reprogramming of fibroblasts into neural stem cells by defined factors. Cell Stem Cell 10: 465-472, 2012.

84. Chang YK, Srivastava Y, Hu C, Joyce A, Yang X, Zuo Z, Havranek JJ, Stormo GD and Jauch R: Quantitative profiling of selective Sox/POU pairing on hundreds of sequences in parallel by Coop-seq. Nucleic Acids Res 45: 832-845, 2017.

85. Bar-Nur O, Verheul C, Sommer AG, Brumbaugh J, Schwarz BA, Lipchina I, Huebner AJ, Mostoslavsky G and Hochedlinger K: Lineage conversion induced by pluripotency factors involves transient passage through an iPSC stage. Nat Biotechnol 33 761-768, 2015.
86. Velychko S, Kang K, Kim SM, Kwak TH, Kim KP, Park C, Hong K, Chung C, Hyun JK, MacCarthy CM, et al: Fusion of reprogramming factors alters the trajectory of somatic lineage conversion. Cell Rep 27: 30-39.e4, 2019.

87. Zou Q, Yan Q, Zhong J, Wang K, Sun H, Yi X and Lai L: Direct conversion of human fibroblasts into neuronal restricted progenitors. J Biol Chem 289: 5250-5260, 2014.

88. Potts MB, Siu JJ, Price JD, Salinas RD, Cho MJ, Ramos AD, Hahn J, Margeta M, Oldham MC and Lim DA: Analysis of Mll1 deficiency identifies neurogenic transcriptional modules and Brn4 as a factor for direct astrocyte-to-neuron reprogramming. Neurosurgery 75: 472-482, 2014.

89. Yu Q, Chen J, Deng W, Cao X, Wang Y, Zhou J, Xu W, Du P, Wang Q, Yu J and Xu X: Direct reprogramming of mouse fibroblasts into neural cells via Porphyra yezoensis polysaccharide based high efficient gene co-delivery. J Nanobiotechnology 15: 82, 2017.

90. Huffman JL and Harmer B: End of Life Care. StatPearls [Internet], StatPearls Publishing, Treasure Island, FL, 2020.

91. Faguet GB: Quality end-of-life cancer care: An overdue imperative. Crit Rev Oncol Hematol 108: 69-72, 2016.

92. Bhagirath D, Yang TL, Tabatabai ZL, Majid S, Dahiya R, Tanaka Y and Saini S: BRN4 is a novel driver of neuroendocrine differentiation in castration-resistant prostate cancer and is selectively released in extracellular vesicles with BRN2. Clin Cancer Res 25: 6532-6545, 2019.

(i) (9) This work is licensed under a Creative Commons Attribution-NonCommercial-NoDerivatives 4.0 International (CC BY-NC-ND 4.0) License. 